solutions.- On diphenylanthrone, by MM. A. Haller and A. Guyot. The researches detailed prove that the substance $\mathrm{C}_{26} \mathrm{H}_{18} \mathrm{O}$ is diphenylanthrone, $\mathrm{C}_{6} \mathrm{H}_{4} \backslash \underset{\mathrm{CO}}{\mathrm{C}(\mathrm{Ph})_{2}}>\mathrm{C}_{6} \mathrm{H}_{4}$. From this established constitution, the phthalyl tetrachloride melting at $88^{\circ} \mathrm{C}$. must have the dissymmetrical formula, $\mathrm{C}_{6} \mathrm{H}_{4}<\mathrm{COCl}_{3}-\mathrm{A}$ new lymphatic gland in the European scorpion, by M. A. Kowalewsky. The gland described has already been made known by J. Müller, who, in 1828 , termed it a salivary gland. -On the laws of friction in sliding, by M. Paul Painlevé. The conclusion is deduced, from the singularities developed in the paper, that the empirical laws of friction are logically inadmissible (even for ordinary pressures and velocities) so soon as the friction becomes at all noticeable. -On the mirage effects and differences of density observed in Natterer's tubes, by M. P. Villard.-On explosive statical and dynamical potentials, by M. R. Swyngedauw.-On direct spectroscopical analysis of minerals and of some fused salts, by M. A. de Gramont. -Determinations of the solubility, at very low temperatures, of some organic compounds in carbon disulphide, by M. Arctowski. Etard found the solubility of substances to be represented for other solvents than water by curves practically of hyperbolic form of which the branches respectively directed themselves towards the points of fusion of the solvent and of the dissolved substance; he even admitted that the solubility would be zero at the point of congelation of the solvent, and infinite at the point of fusion or ebullition of the dissolved substance. The author finds, with carbon disulphide, that the point of fusion of the solvent appears not to be an essential point on the curve of solubilities; and it is otherwise known that the property of dissolving is not an exclusive property of the liquid state of matter.-On some oxidising properties of ozonised oxygen and of oxygen in sunlight, by M. A. Besson.--Action of nitric oxide on some metallic chlorides : ferrous, bismuth, and aluminium chlorides, by M. V. Thomas. A fine red ferrous compound has been obtained of the formula $5 \mathrm{Fe}_{2} \mathrm{Cl}_{4}$. NO. By decomposition of this, or by suitably heating anhydrous $\mathrm{Fe}_{2} \mathrm{Cl}_{4}$ in a current of nitric oxide, yellowish brown $\mathrm{Fe}_{2} \mathrm{Cl}_{4} . \mathrm{NO}$ is obtained. A fine yellow bismuth compound and a pale yellow aluminium compound have aiso been obtained. They are very hygroscopic substances, and have the composition $\mathrm{BiCl}_{3} . \mathrm{NO}$ and $\mathrm{Al}_{2} \mathrm{Cl}_{6} \cdot \mathrm{NO}$ respectively.Action of halogens on methyl alcohol, by M. A. Brochet.--On a physical theory of the perception of colours, by M. Georges Darzens. - On the presence and the rôle of starch in the embryonic sac of Cacti and Mesembryanthema, by M. E. d'Hubert. The observations favour the view that starch serves to preserve the embryonic sac in these plants in that state which characterises the ripe and readily fertilised sac.--On the tectonic characters of the north-west part of the Alpes-Maritimes department, by $M$. Leon Bertrand. - An inferior maxillary human bone found in a grotto in the Pyrenees, by MM. Louis Roule and Felix Regnault. From the characters of the bone described and other similar remains it is concluded that : In the time of the great Cave-bears, France was inhabited by a human race of normal height with a flat and powerful lower jaw.

\section{New South Wales}

Linnean Society, May 29.-Mr. P. N. Trebeck in the chair.-Oological notes (continued), by A. J. North. - Note on the correct habitat of Patella (Scutellastra) kermadecensis, Pilsbry, by T. F. Cheeseman.-On two new genera and species of fishes from Australia, by J. Douglas Ogilby.-Descriptions of new species of Australian Coleoptera, Part II., by Arthur M. Lea. This paper comprises descriptions of over one hundred species, for the most part referable to the families Malacodermide, Mordellide, Anthicida, and Corylophide.-Lifehistories of Australian Coleoptera, Part III., by W. W. Frog gatt. - Description of a giant Acacia from the Brunswick River, New South Wales, by J. H. Maiden. This Acacia was col lected by Mr. W. Bäuerlen on Tergoggin Mountain and on Mullumbimby Creek, Brunswick River, N.S.W. As far as known, it is confined to brushes, as distinguished from open forest. It attains a height of 120 feet and a diameter of 5 feet ; it is therefore one of the largest of the genus. Its closest affinity is with $A$. binervata, from which it differs in the structure of the flowers, seeds, and pod, and in other less important particulars. The inflorescence is in loose, elongated panicles or racemes, with peduncles in clusters. The flowers are few-never more than twenty--with villous petals and sepals, which are spathulate and tetramerous. The pod is nearly six lines broad, thin and straight. The author proposes the name of Acacia Bakeri for the species, in honour of his colleague, Mr. R. T. Baker.

\section{BOOKS, PAMPHLETS, and SERIALS RECEIVED.}

Books.-Open-Air Studies: Prof. G. A. Cole (Griffin),-A Garden of Pleasure (E. Stock). - Dr. Schlich's Manual of Forestry, Vol. 4 (Bradbury). -The Alps from End to End: Sir W. M. Conway (Constable). - Nature zerersus Natural Selection: C. C. Coe (Sonnenschein).-Microbes and Disease Demons : C. Berdoe (Sonnenschein).-The Climates of the Geological Past: E. Dubois (Sonnenschein).--Physikalisch-Chemische Propaedentik Erste Halfte: Prof. H. Griesbach (Leipzig, Engelmann).-Die Physiologie der Geruchs: Dr. A. Z waardemaker (Engelmann).-Experimental Plant Physiology : D. T. Macdougal (Holt and Co., New York).

PAMPHLETS.-Static and Dynamic Sociology: L. F.' Ward (Boston, Ginn and Co.).-On Kaloxylon Hookeri and Lyginodendron Oldhamium T. Hick.-On the Structure of the Leaves of Calamites (Manchester). - Report of the Trustees of the South African Museum for 1894 (Cape Town).- Returns of Agricultural Statistics of British India, \&c. 1893-4 (Calcutta). Studies on the Dissemination and Leaf Reflexion of Yucca Aloifolia: $\mathrm{H}$ J. Webber (Missouri Botanic Garden)--On the Osteology of Agriochneus: J. L. Wortman (New York). - Fossil Mammals of the Uinta Basin Expedition of $1894:$ H. F. Osborn (New York).

tion of x 894 : H. F. Osborn (New York).
Serials. - Journal of the Royal Statistical Society, June (Stanford).SERIALS. - Journal of the Royal Statistical Society, June (Stanford).
Record of Technical and Secondary Education, July (Macmillan and Co.). Record of Technical and Secondary Education, July (Macmillan and Co.). July (Macmillan and Co.).--Engineering Magazine, July (Tucker).-July (Macmillan and Co.).-Engineering Magazine, July (Tucker).--
Medical Magazine, July.-Natural History of Plants, Part I4 (Blackie).Medical Magazine, July.-Natural History of Plants, Part I4 (Blackie).-
Tokyo Sugaku-Butsurigakaukwai Kizi Maki, No. vi. Dai 1 and 2 (Syup. Tokyo Sugaku-Butsurigakaukwai Kizi Maki, No. vi. Dai $~$
pan). - Journal of and 2 (Syup.
the Franklin Institute, July (Philadelphia). - Bulletin of pan). - Journal of the Franklin Institute, July (Philadelphia). - Bulletin of
the American Mathematical Society, June (Macmillan and Co., New the American Mathematical Society, June (Macmillan
York). - Bulletin of the Johns Hopkins Hospital (Baltimore).

\section{CONTENTS.}

PAGE

Analysis of Oils, Fats, and Waxes. By L. Arch-

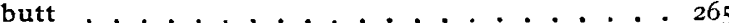

Traces of a Deluge. . . . . . . . . 266

An Eclectic History of Science . . . . . . 267

Microscopic Study of Rocks. By G. T. P. . . . 267

Our Book Shelf :-

Wright: "Garden Flowers and Plants : a Primer for

Amateurs" . . . . . . . . . . . 268

Wells : "The Time Machine" ........ 268

\section{Letters to the Editor:-}

The Teaching University for London.--..Right Hon.

Sir John Lubbock, Bart., F.R.S. . . . . . . 268

The Density of Molten Rock.-Prof. Oliver J.

Lodge, F.R.S.

The Earliest Magnetic Meridians.-Dr. L. A. Bauer 269

Curious Habit of the Spotted Flycatcher.-Rev. W.

Clement Ley . . . . . . . . . . . . 269

A Brilliant Meteor.-Charles B. Butler . . . . . 269

Newton and Huygens. (With Diagram).-A. Huet 269 The International Catalogue of Scientific Papers . 270 Science Scholarships at Cambridge . . . . . . . 27 I Scale Lines on the Logarithmic Chart. (With Diagram.) By C. V. Boys, F.R.S. . . . . . . 272

Notes ........... . . 274

Our Astronomical Column:-

The New Madras Observatory . . . . . . . 277

Star Catalogues . . . . . . . . . . . 278

The Place of Argon among the Elements . . . . 278

Pocket Gophers of the United States . . . . . 278

Colour Photography . . . . . . . . . . . . 279

The Slate Mines of Merionethshire . . . . . . 279

The Relation of Biology to Geological Investiga-

tion. II. (With Diagram.) By Charles A. White 279 University and Educational Intelligence .... 284 Scientific Serials ............. 284 Societies and Academies ......... . 285 Books, Pamphlets, and Serials Received ... . 288 No. I 342 , VOL, 52$]$ 